\title{
Geotechnical characterization of Beka-Gotto rock massif (Adamawa- Region Cameroon) for the use in civil engineering
}

\author{
Abdoul Aboubakar ${ }^{1,2, *}$, Bertille Illalie Manefouet ${ }^{2}$, Landrie Sylvin Komguep², Emmanuel Tatchoum \\ Talom $^{2}$, Clotaire Romaric Foueze ${ }^{2}$, Yannick Lahe Djonthu ${ }^{1}$ \\ ${ }^{1}$ Center for Geological and Mining Research (CRGM), P.O. Box: 333, Garoua, Cameroon \\ ${ }^{2}$ Départment of Earth Sciences, Faculty of Sciences, University of Dschang, P.O. Box: 67, Dschang, Cameroon \\ *Corresponding author's email: abdoulcraft8@gmail.com
}

\begin{abstract}
Beka-Gotto is a village of Ngaoundal located in the Adamawa region (Cameroon). The present study is carried out to determine the physical and mechanical characteristics of the local rock massifs, in order to determine their possible uses in various fields of civil engineering. The methodology used consists of petrographic and geotechnical characterization of the different massifs. The rocks crop out as domes or slabs. The rock is light gray. Under the microscope, the rock presents a grainy microstructure composed of plagioclase, potassium feldspar, biotite and quartz. Zircon and opaque minerals represent the accessory phase. With this composition, rock is granodiorite. The geotechnical study, on the other hand, made it possible to understand that, on the physical level, the rock massif has very good properties. In fact, the specific weight on class $6 / 10$ and $10 / 14$ obtained has mean values of 2.73 and $2.68 \mathrm{kN} / \mathrm{m}^{3}$ respectively. While the apparent density obtained of the class $6 / 10$ and 10/14 has mean values 1.35 and $1.46 \mathrm{~g} / \mathrm{cm}^{3}$ respectively. Mechanically, Los Angeles coefficient is $24-$ $46.3 \%$ while the Micro-Deval coefficient is $7-35 \%$ and the coefficient of dynamic fragmentation is $18-30 \%$. In accordance with geotechnical standards, with the exception of the Gbago massif, the other massifs have a choc resistance and a wear resistance of satisfactory to limited grade as well as good resistance to dynamic fragmentation and therefore usable in any type of structure.
\end{abstract}

Keywords: Geotechnics; Petrography; Beka-Gotto; Civil engineering; Rock massif

Received: 15 March, 2021 Received in revised form: 13 July, 2021 Accepted: 14 July, 2021

\section{INTRODUCTION}

Cameroon is a country where the construction of buildings, roads or other masterpieces is undergoing rapidly. It cannot therefore achieve a harmonious development in the field of infrastructure if the local materials are not characterized before being exploited. This requires knowledge of their genetic type and their distribution at the local, regional, and national levels. The search for quarry borrowings has become a major priority in the execution of public works. It was with this same idea that mining and quarrying the $10^{\text {th }}$ conference on the building materials construction was held in Algeria from March 27 to 28, 2018 under the theme: "Building materials construction and sustainable development", (NOMAD, 2012).

Cameroonian territory covers a large area $(475,442$ $\mathrm{km}^{2}$ ) with different sedimentary, magmatic and metamorphic rock terrains. It has been demonstrated that knowledge and geotechnical engineering characterization of construction materials in Cameroon will allow the development of several national economy sectors as well as the generation of jobs.

The study area is located in Beka-Gotto, in the
Adamawa Region, Cameroon, more precisely in the Djerem Department within Ngaoundal district. The geographical coordinates that bound Beka-Gotto is $6^{\circ}$ $45^{\prime}$ and $6^{\circ} 65^{\prime}$ North latitude and $13^{\circ} 55^{\prime}$ and $13^{\circ} 70^{\prime}$ East longitude with an average elevation of $1043 \mathrm{~m}$ (Fig. 1).

The main objective of this work is to assess the quality aggregates for civil engineering work, which may contribute to resolving the lack of building materials in the Adamawa region, particularly in the Djerem department. The study consists of a petrographic description at the sample scale and the deposit scale along with the analysis of the rock resistance parameters like Los Angeles, Micro-Deval, and Dynamic Fragmentation.

\section{GEOLOGY AND GEOMORPHOLOGIC SETTING}

The Pan-African Chain of Central Africa (CPAC) also called mobile zone of Central Africa (Lassere 1966; Lasserre and Soba, 1979; Bessoles and Trompette 1980; Affaton et al., 1991), corresponds to a wide zone that extends north of the Congo Craton and is limited to the west by the Trans-Saharan chain. 

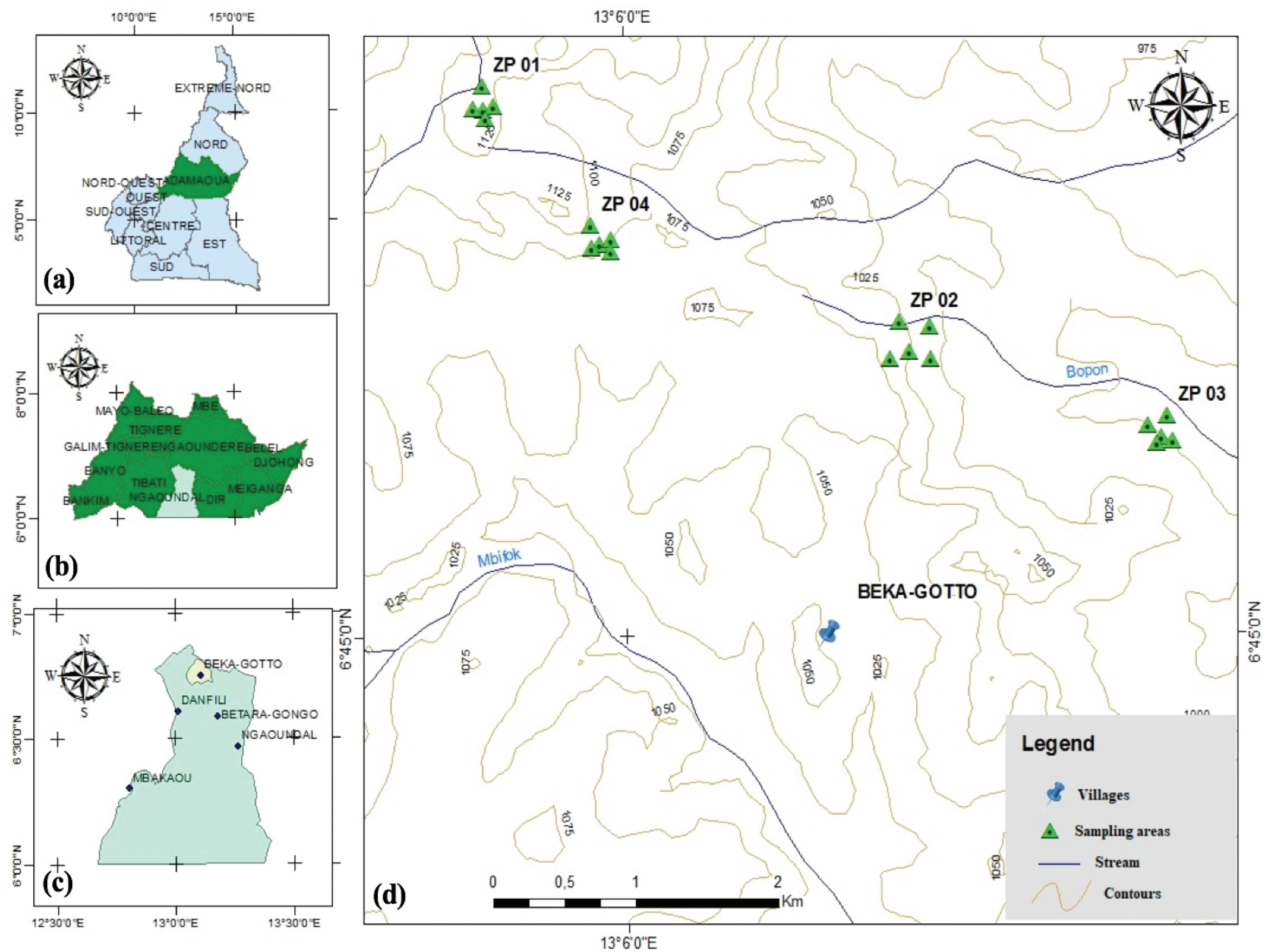

Fig. 1: Location of the study area: (a) Administrative map of Cameroon; (b) Map of Adamawa region; (c) Map of the study area in the district of Ngaoundal; (d) Topographic map of the study area.

Petrographic, structural and geochronological studies have permitted subdivision of the CPAC into three lithostructural domains: the North, Center, South Cameroon domains, (Fig. 2a) (Ngako, 1999; Toteu et al., 2004, Van Shumus et al., 2008). The study area is composed of various geological formations, including: a base granite covered in places by volcanic formations represented by anatexis derived granites and biotite anatexites (Fig. 2b).

Segalen (1967) and Kamgang K. (1998) presented a geomorphological sketch of Cameroon, which allows us to distinguish four major units' characteristics, namely, regions of low altitudes, intermediate reliefs, planning surfaces and mountains. The BekaGotto area belongs to the South Cameroon Plateau characterized by low-relief surfaces and mountains with altitudes that vary between $740 \mathrm{~m}$ and $1850 \mathrm{~m}$. The map of the digital terrain model emerged from the geographical coordinates recorded in the field and digitization of the background topography, and show that the altitudes in the study area vary between $740 \mathrm{~m}$ and $1300 \mathrm{~m}$ (Fig. 3).

The Beka-Gotto village is bounded by the following mountain ranges: Gabiskedje and Ngoulouk in the north, NgaouHola and Balina in the east and NgaouNdoum, in the south (Fig. 3).

An aggregate is a granular material used in the construction industry, either linked to other substances (binder, bitumen) to obtain mortar, concrete, road concretes, etc., or unbound such as railroad ballasts, aggregates for the drainage system. It is made up of several mineral grains of different dimensions in which most frequently between $0 \mathrm{~mm}$ and $125 \mathrm{~mm}$ but can go up to $150 \mathrm{~mm}$. Aggregate is either natural or artificial in origin. Table 1 shows the range of granular classes and their application at various levels of construction. During this study, the $6 / 10 \mathrm{~mm}$ and $10 / 14 \mathrm{~mm}$ granular classes are the subject of our study, because these two classes are the most used in road construction. 

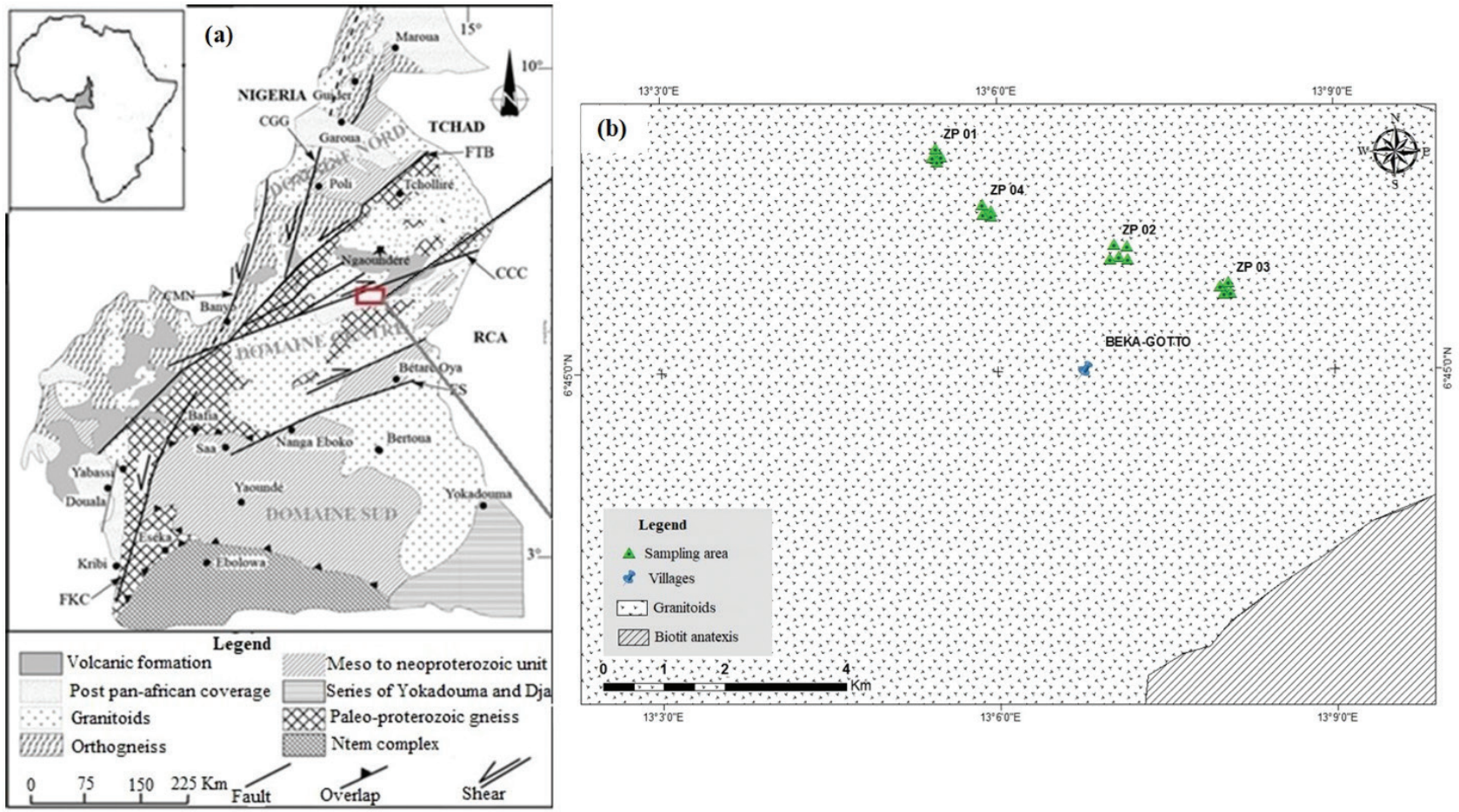

Fig. 2: (a) Simplified geological map showing the Pan-African chain from Central Africa to Cameroon indicating the three domains (Toteu et al., 2001) (b) Simplified geological map showing the study sector (Dumort (1968). FKC = Kribi-Campo fault; FS = Sanaga fault; CCC $=$ Shear Cameroon Center; CGG = Godé-Gormayashear; $\mathbf{C M N}=$ Mayo-Nolti Shear; TBF = Tcholliré-Banyo fault.

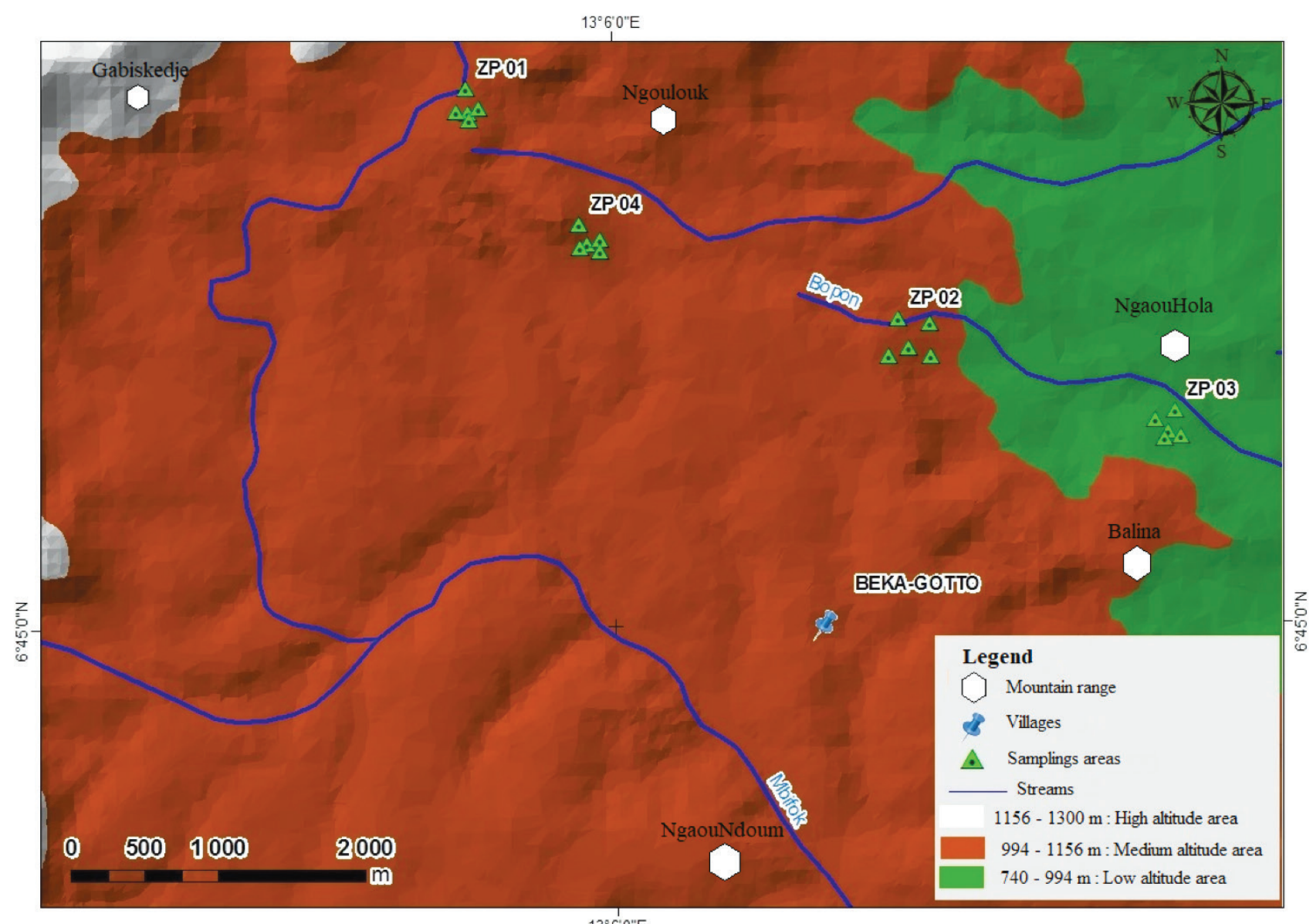

$13^{\circ} 6^{\circ} 0^{\circ E}$

Fig. 3: Digital terrain model of the study area (After Dumort, 1968). 
Table 1: The different classes of aggregates with their use in civil engineering.

\begin{tabular}{|c|c|c|c|c|c|c|c|}
\hline \multirow{2}{*}{\multicolumn{2}{|c|}{ Granular class $(\mathrm{mm})$}} & \multicolumn{6}{|c|}{ Usage } \\
\hline & & Concrete & Mortar & Backfill & $\begin{array}{l}\text { Foundation } \\
\text { layer }\end{array}$ & $\begin{array}{l}\text { Base } \\
\text { layer }\end{array}$ & $\begin{array}{c}\text { Bearing } \\
\text { layer }\end{array}$ \\
\hline & $0 / 2$ & - & - & & & & - \\
\hline & $0 / 5$ & - & - & & & & \\
\hline & $4 / 6$ & $\bullet$ & $\bullet$ & & & & $\bullet$ \\
\hline & $2 / 6$ & - & & & & & - \\
\hline & $5 / 10$ & - & & & & & - \\
\hline & $6 / 10$ & - & & & & & - \\
\hline \multirow[t]{10}{*}{ Granite } & $5 / 15$ & - & & & & & \\
\hline & $10 / 14$ & - & & & & & - \\
\hline & $10 / 20$ & & - & & & & \\
\hline & $15 / 25$ & - & & & & & \\
\hline & $25 / 50$ & \multicolumn{6}{|c|}{ Ballasts for railways } \\
\hline & $0 / 31,5$ & \multirow{2}{*}{\multicolumn{6}{|c|}{ - }} \\
\hline & $0 / 150$ & & & & & & \\
\hline & Riprap & \multirow{2}{*}{\multicolumn{6}{|c|}{ Hydraulic works; civil engineering works; supports. }} \\
\hline & $0 / 40$ & & & & & & \\
\hline & $40 / 125$ & \multicolumn{6}{|c|}{ Sanitation } \\
\hline
\end{tabular}

\section{MATERIAL AND METHODS}

In order to achieve the objectives, a brief study, relating to the Adamawa Region geology as well as specific study of Ngaoundal in particular was carried out. Four sampling areas were identified and samples were collected (Fig. 4). Samples were documented according to their location, their lithology and their degree of alteration.

At each area, approximately $75 \mathrm{~kg}$ of material was collected in bags for laboratory analysis. Representative samples were taken and placed in plastic packaging for thin section preparation. The

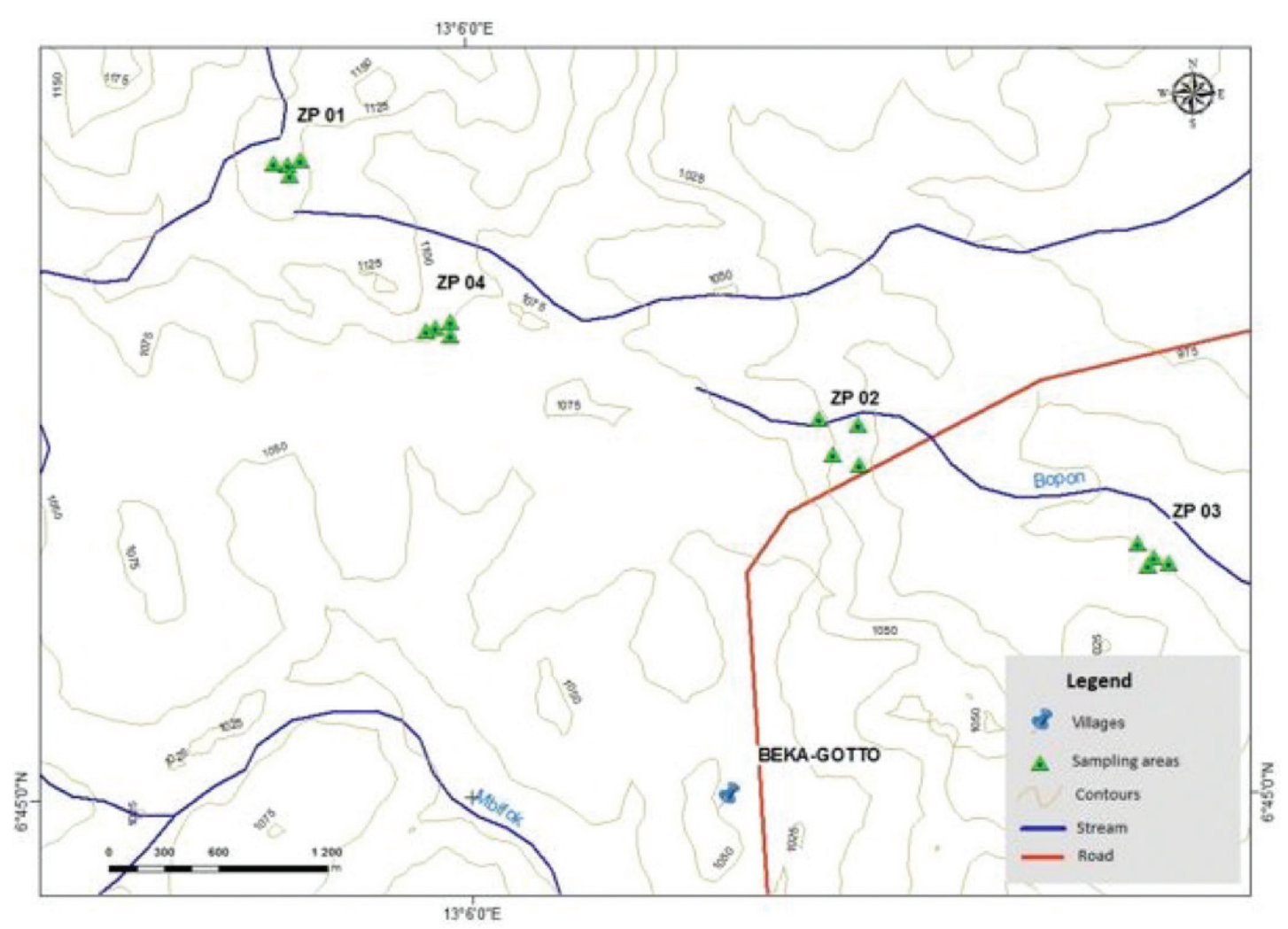

Fig. 4: Map showing the sample location. 
numbering of each location are ZP01 to ZP04 for geotechnical tests in the A-Z Consulting laboratory.

In the A-Z Consulting laboratory at Yaoundé, five tests were carried out, namely:

- Bulk density;

- $\quad$ Specific weight (NFP 94-054);

- Los Angeles or Abrasion Test (EN 1097-2);

- $\quad$ Micro-Deval (EN 1097-1);

- Dynamic fragmentation.

Table 2 shows the operating mode of the various geotechnical analyzes carried out in the laboratory.
The petrographic thin sections were prepared from the most fresh, unweathered and unaltered representative samples. The description of thin sections was used to determine petrographic characteristics. In addition, geotechnical engineering tests, particle size analysis, and both the Los Angeles test and the Micro-Deval test were conducted. Crushing by dynamic fragmentation was used for the production of class $6 / 10$ and 10/14 aggregates. Los Angeles and Micro-Deval tests were conducted to determine the respective resistances of abrasion, crushing and grinding. In addition, the Kurtosis coefficient, specific weight, and apparent density were calculated.

Table 2: Methodology of different analysis carried out in the laboratory.

\begin{tabular}{lll}
\hline Test & Principle & Operating mode \\
\hline Bulk density & It is possible to & The principle consists of looking for 03 successive weighing values with a \\
& determine the apparent & maximum deviation of $50 \mathrm{~g}$. The material used consists of a mold of known \\
density of the material, volume, a scale, a tray and a plane. The bulk density pa is determined using \\
that is to say the quantity the formula \\
of materials contained \\
in a given volume.
\end{tabular}

Specific It is possible to The mass of solid particles is obtained by weighing, and the volume is
weight NF determine the real measured with a pycnometer.

P94-054. density of the material, taking into account the The real density $\boldsymbol{P S}$ of solid particles is obtained from the formula:

voids present in the $\boldsymbol{P}_{S}=\boldsymbol{P}_{w}\left(\boldsymbol{m}_{2}-\boldsymbol{m}_{\mathbf{P}}\right) /\left(\boldsymbol{m}_{4}+\boldsymbol{m}_{2}-\boldsymbol{m}_{1}-\boldsymbol{m}_{3}\right)$ rock.

Where, $\boldsymbol{P}_{w}$ is the density of water $(1000 \mathrm{~kg} / \mathrm{m} 3), \mathrm{m} 1$ is the mass of the empty pycnometer, $\mathrm{m} 2$ the mass of the pycnometer + aggregates, $\mathrm{m} 3$ the mass of the pycnometer + aggregates + water and $\mathrm{m} 4$ the mass of the full pycnometer water in grams.

Los Angeles It is possible to The test is started by performing the machine 500 rotations at a speed between or Abrasion measure the combined 30 and $35 \mathrm{rpm}$ for all classes except the 25-50 mm class where the number of Test EN resistances to shocks rotations is 1000 .

1097-2 and to the progressive deterioration reciprocal friction of the elements of an aggregate.
After the test, the aggregates are removed and collected in the tank placed under the apparatus to prevent losses of the aggregates, the opening must be made above this tank. The material contained in the tank is crushed on the

$1.6 \mathrm{~mm}$ sieve and then the $1.6 \mathrm{~mm}$ residue is washed in another tank and it is poured into the perforated tank. As soon as the residue is dried in an oven then the weights of the M1 weighing are determined, and the Los Angeles coefficient is then calculated:

\section{LA=100X (M-M1)/M}

Micro-Deval It determines the Reproducing wear phenomena in a rotating cylinder and consists in measuring EN 1097-1 resistance to wear by the wear of the aggregates under standardized conditions produced by mutual the reciprocal friction friction, in the presence of water and an abrasive load in a rotating cylinder.

of the elements of an Let $M$ be the mass of the material tested and $m$ is the mass of the elements aggregate. smaller than $1.6 \mathrm{~mm}$ produced during the test; wear resistance is expressed by the Micro-Deval coefficient which is written: 


\section{RESULTS}

\section{Contribution of the petrographic study}

The rocks out crops occur as domes or slabs (Fig. 5a and $5 \mathrm{~b}$ ). The rock is light gray in color and the visible minerals are quartz, feldspar, and biotite.
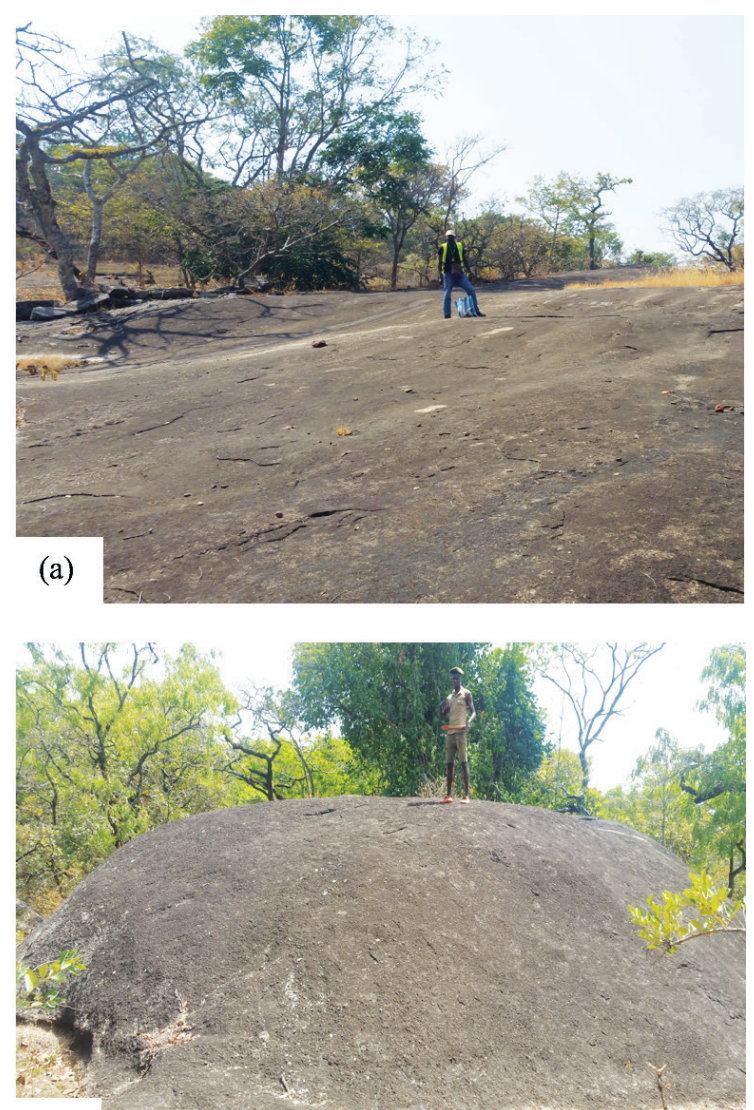

(b)

Fig. 5: Photographs of Bahkosso and Gbago granite massifs. (a) Slab outcrop of the Bahkosso granite. (b) Slaboutcrop of the Gbago granite.

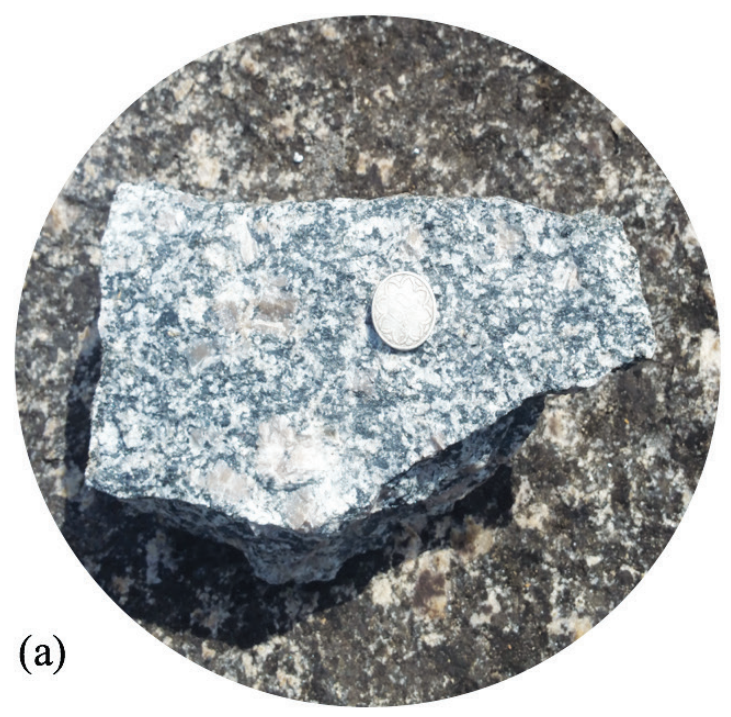

In thin section, the rock shows a grainy microstructure composed of plagioclase, potassium feldspar, biotite, and quartz and some minerals are clear in hand specimens (Fig. 6a and 6b). In addition, zircon and opaque minerals represent the accessory minerals. Plagioclase (25-30\%) is in the form of subautomorphic crystals of variable size between 1 x 0.5 $\mathrm{mm}$ and $1.25 \times 1.8 \mathrm{~mm}$. These plagioclase crystals are associated with potassium feldspar crystals and sometimes contain biotite inclusions. These minerals are also associated with quartz, and biotite lamellae (Fig. 6b and Fig. 8b). Alkaline feldspar (20$25 \%$ ) is represented by microcline and orthoclase. Their crystals appear as large sub-automorphic to automorphic patches. The larger ones sometimes reach $1.5 \mathrm{~mm}$ long and sometimes exceed $0.93 \mathrm{~mm}$ in the minor axis. Some K-feldspar crystals contain opaque mineral inclusions while biotite flakes mold others. Some alkaline feldspar crystals are perthitic and others are myrmeckitic (Figs. 7a and 7b).

Quartz (15-20\%) occurs in the form of polycrystalline, sub-automorphic to xenomorphic plaques up to 1.6 $\mathrm{mm}$ long axis. Large quartz crystals are frequently associated with feldspar patches, while small subautomorphic crystals are often clustered around plagioclase crystals (Fig. 8a). They exhibit for the most part rolling extinction. Biotite $(10-15 \%)$ is in the form of flakes in the rock and may be in contact with feldspar, quartz, some biotite flakes show the start of alteration to chlorite, and others contain inclusions of zircon crystals. It is automorphic to subautomorphic, weakly pleochroic, between light green and dark green. The association of biotite flakes, alkaline feldspar hornblende crystals, and quartz is common. Hornblende (5\%) occurs as subautomorphic

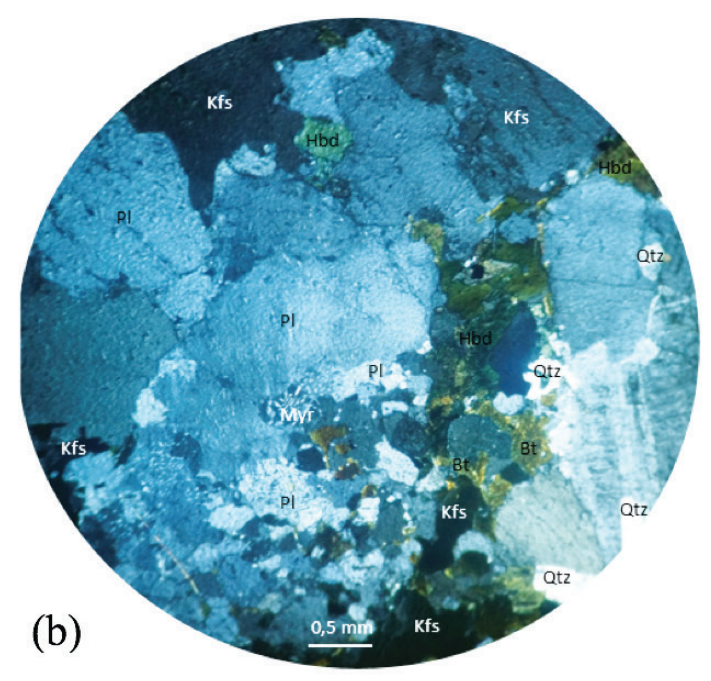

Fig. 6: Photograph and photomicrograph of biotite and amphibole granite (a). Sample of biotite and amphibole granite. (b) Microstructure showing all the minerals of the rock. Bt: Biotite; Kfs: Potassic Feldspar; Myr: Myrmekite; PI: Plagioclase; Qtz: Quartz. 

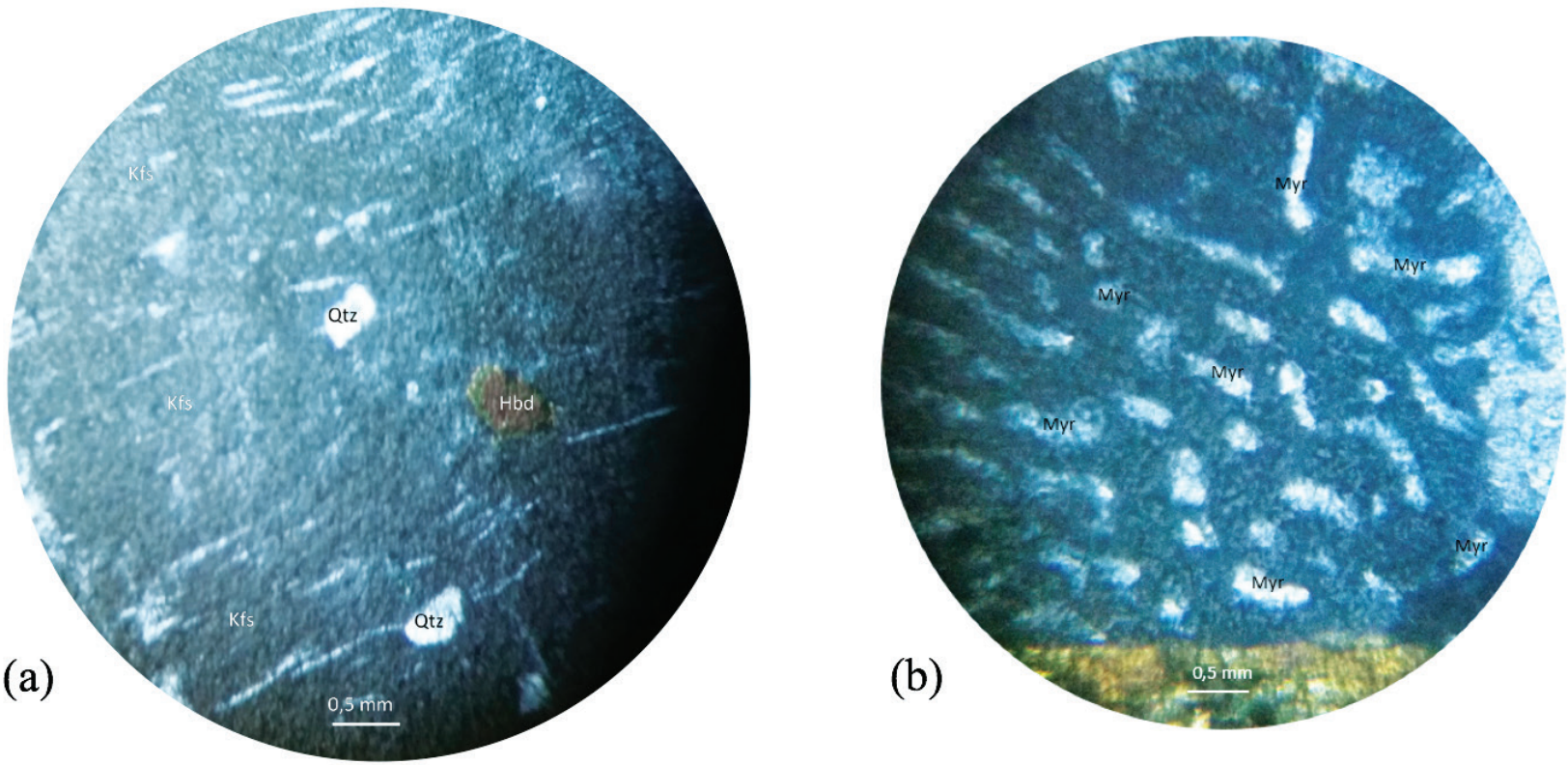

Fig. 7: Photomicrograph of biotite and amphibole granite (a) image showing perthite and inclusion of quartz and hornblende in the plagioclase (b) image showing Myrmekite texture. Hbd: Hornblende; Myr: Myrmekite; Qtz: Quartz.

(a)

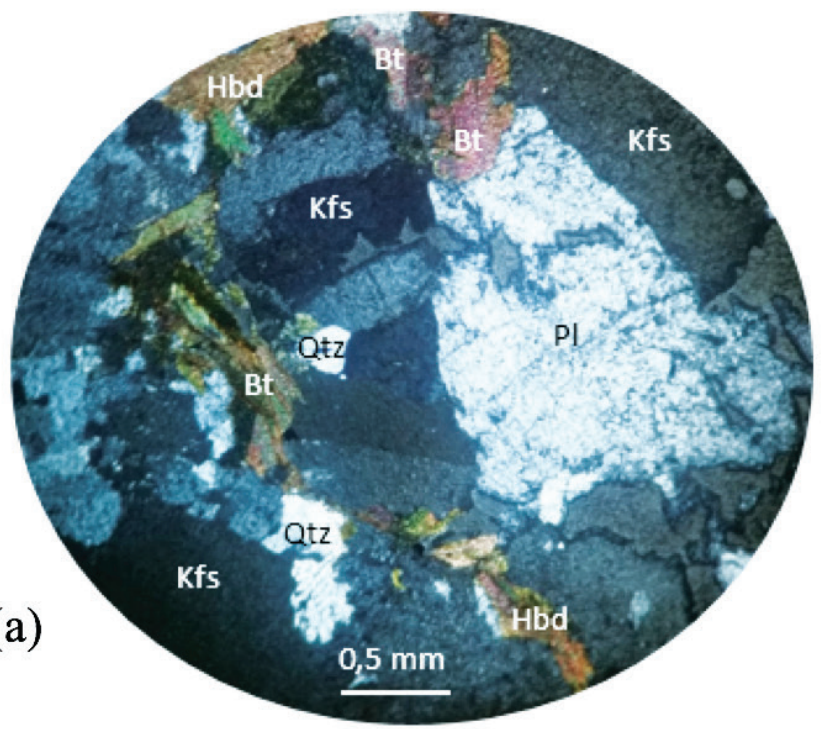

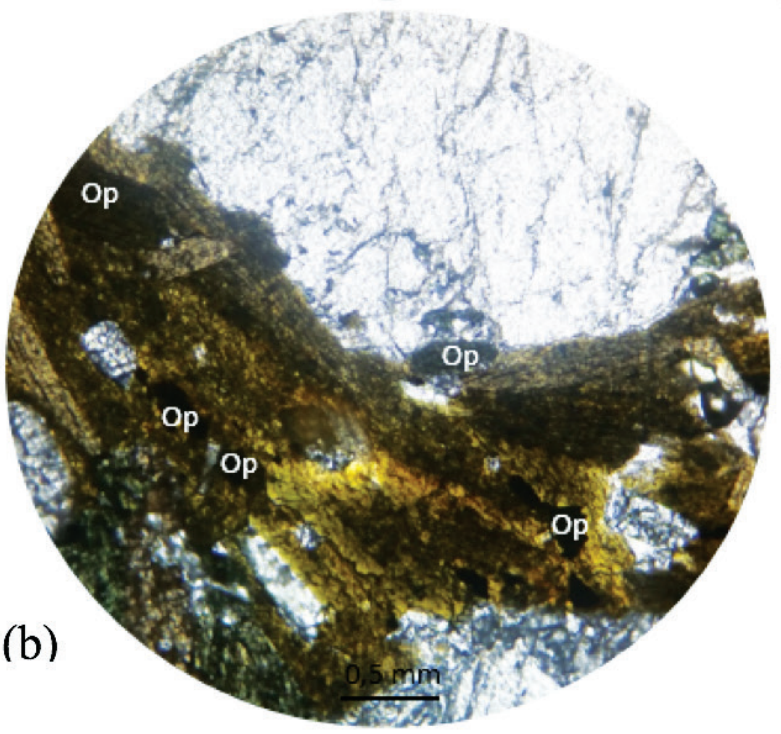

Fig. 8: Photomicrograph of biotite and amphibole granite (a) image showing the mineralogical association PI + Kfs + Qtz + Bt. (b) Image showing inclusions of opaque minerals in the amphibole. Bt: biotite; Hbd: Hornblende; Kfs: Potassic Felspar; Op: opaque; PI: Plagioclase; Qtz: Quartz.

to automorphic crystals up to $1.25 \times 0.75 \mathrm{~mm}$ in size. Some feldspar crystals have inclusions of opaque minerals and others are included in plagioclase crystals. Opaque minerals $(<3 \%)$ are in the form of smaller automorphic crystals included in other minerals (biotite, plagioclase) or dispersed in the matrix. Zircon $(<2 \%)$, in automorphic crystals with a radioactive halo, is generally found in inclusion in biotite lamellae. Since the rock is a granodiorite, it is characterized by the following mineral association: P1 $+\mathrm{Kfs}+\mathrm{Qtz}+\mathrm{Bt}$ (Fig. 8e).

\section{Contribution of the geotechnical study}

Table 3 presents the results of physical and mechanical characterization of the samples taken from the granite massifs. The bulk density test carried out on two granular classes (6/10 mm; 10/14 mm) of four samples taken shows that the bulk density of the different samples varies between 1.42 and 1.49 as shown in Fig. 9a.

The results of the specific weight achieved on two granular classes $(6 / 10 \mathrm{~mm} ; 10 / 14 \mathrm{~mm})$ of the four 
Aboubakar et al.

Table 3: Geotechnical analysis results.

\begin{tabular}{lllllll}
\hline Samples & $\begin{array}{c}\text { Granular class } \\
(\mathrm{mm})\end{array}$ & $\begin{array}{c}\text { Apparent } \\
\text { density }\left(\mathrm{g} / \mathrm{cm}^{3}\right)\end{array}$ & $\begin{array}{c}\text { Specific } \\
\text { weight } \\
\left(\mathrm{kN} / \mathrm{m}^{3}\right)\end{array}$ & $\begin{array}{c}\text { Coefficient } \\
\text { LA }(\%)\end{array}$ & $\begin{array}{c}\text { Coefficient } \\
\text { MD (\%) }\end{array}$ & $\begin{array}{c}\text { Coefficient } \\
\text { FD (\%) }\end{array}$ \\
\hline ZP01 & \multicolumn{1}{c}{ 6/10 } & 1.42 & 2.61 & 31.5 & 9 & 20 \\
& $10 / 14$ & 1.46 & 2.62 & 24.7 & 8 & 21 \\
ZP02 & $6 / 10$ & 1.47 & 2.67 & 43.0 & 35 & 30 \\
& $10 / 14$ & 1.49 & 2.64 & 46.3 & 38 & 29 \\
ZP03 & $6 / 10$ & 1.42 & 2.67 & 30 & 7 & 21 \\
& $10 / 14$ & 1.45 & 2.77 & 33 & 8 & 19 \\
ZP04 & $6 / 10$ & 1.43 & 3.00 & 28 & 7 & 18 \\
& $10 / 14$ & 1.43 & 2.72 & 30 & 7 & 19 \\
\hline
\end{tabular}

samples shows that the value of the specific weight of the samples varies between $3.00 \mathrm{~kg} / \mathrm{m}^{3}$ and $2.61 \mathrm{~kg} /$ $\mathrm{m}^{3}$ as shown in Fig. $9 \mathrm{~b}$.

Regarding the mechanical parameters, the results of the Los-Angeles test on granular classes $6 / 10 \mathrm{~mm}$ and $10 / 14 \mathrm{~mm}$ have a variation of the coefficient from $24.7 \%$ to $46.3 \%$ as shown in Fig. 10 . The results of the Micro-Deval test carried out in the two granular classes $6 / 10 \mathrm{~mm}$ and $10 / 14 \mathrm{~mm}$ with a test sample mass of $5000 \mathrm{~g}$ vary from $7 \%$ to $38 \%$ (Fig. 10a). The results of the dynamic fragmentation test of the rock presents the coefficients that are $20 \%, 30 \%, 21 \%$, and $18 \%$ respectively. The coefficient is obtained according to the granular class 10/14 and with a test setting mass of $350 \mathrm{~g}$. We noticed a slight variation between the different massifs $(20 \%, 30 \%, 21 \%$, and $18 \%$ ). Three quarters of the massifs studied present an almost identical resistance to fragmentation as shown in the diagram in Fig. 10b.

The results of the geotechnical tests obtained on these rock samples are interpreted based on the guide for evaluating the quality and durability of the materials is presented in Table 4 .

According to the evaluation guide of a materials quality and durability, think that apart from the Gbago

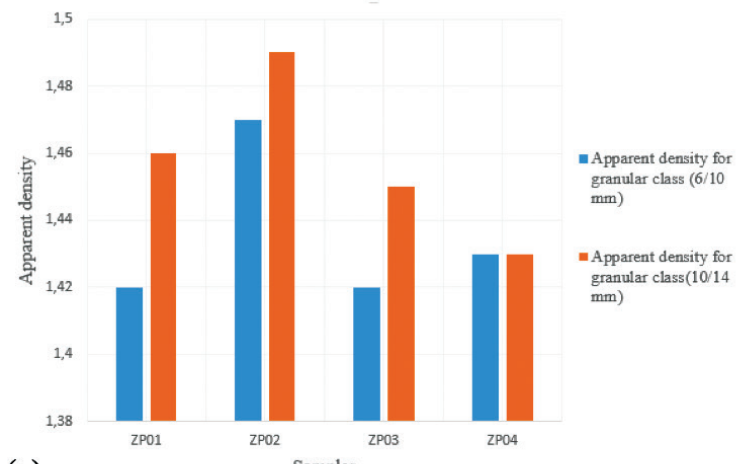

(a)

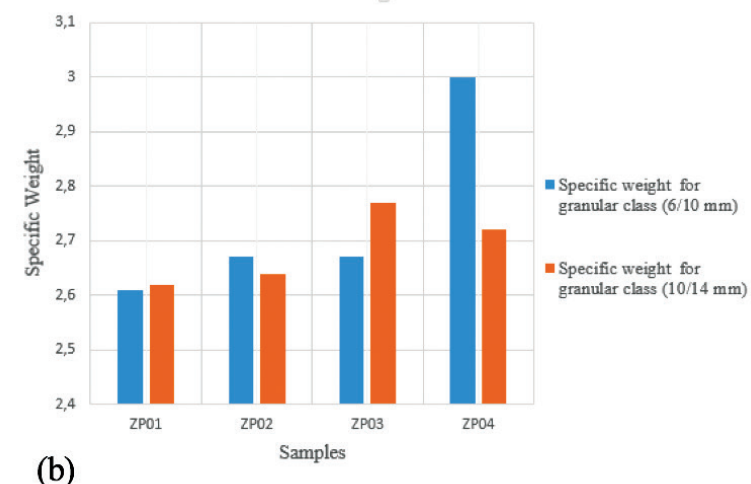

Fig. 9: Histogram of the physical tests. (a) Apparent density; (b) Specific gravity.

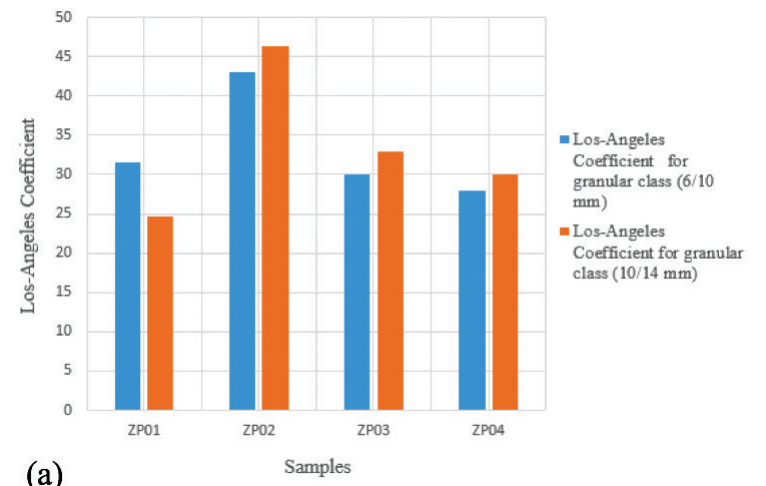

(a)

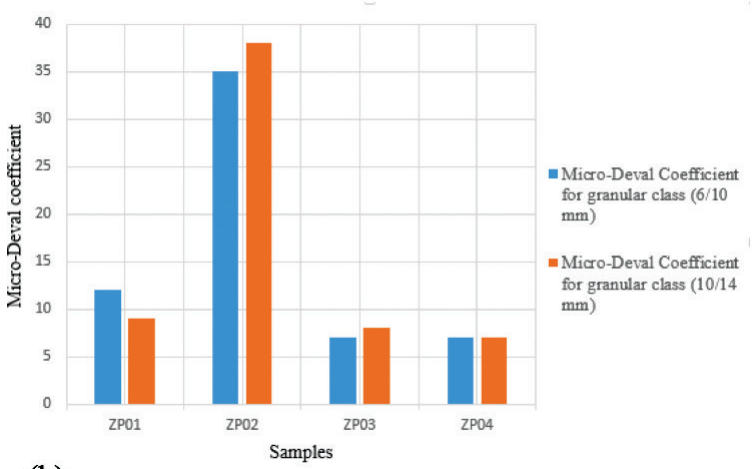

(b)

Fig. 10: Histogram of mechanical tests (a) Los Angeles coefficient (b) Micro-Deval Coefficient. 
Table 4: Guide for evaluating the quality and durability of materials.

\begin{tabular}{llllll}
\hline Criteria & Standard & Excellent & Satisfactory & Limited & Poor \\
\hline Los Angeles test $\quad(\%)$ & EN 1097-2 & $<15$ & $15-25$ & $25-35$ & $>35$ \\
Specific weight test & EN 13383-2 & $>2,7$ & $2.5-2.7$ & $2.3-2.5$ & $<2,3$ \\
Micro-Deval test (\%) & EN 1097-1 & $<10$ & $10-20$ & $20-30$ & $>30$ \\
\hline
\end{tabular}

massif (ZP02), which presents mediocre resistance, the other three massifs have limited resistance (Table 4). However, resistance to the abrasion slightly varies depending on the grain size variation and the cohesion between the grains. A rock made up of quartz or fine- to medium-grained minerals have good resistance as compared to those made up of coarsegrained minerals. Therefore, the lower the resistance to fragmentation, better the material is. A granite material with a Los-Angeles coefficient $>35 \%$ is not usable in road construction. Therefore, beside the ZP02 massive, the remaining three other massifs can be used in site construction and in the formulation of concrete and mortars. Nevertheless, the granular classes 10/14 and 6/10 can be recommended for the construction of traffic road T4-T5 because their value are less than 30 .

It should be noted that the resistance of a rock is linked to its mineralogical composition and degree of weathering. A rock that is made up of ferromagnesian or weathered minerals generally gives poor results to mechanical resistance because there is inadequate cohesion between the grains. However, the lower the abrasion resistance, the more the material becomes excellent. After comparing our results to those in table 4, we can therefore say that the three massifs (ZP01, ZP03 and ZP04) could be suitable for the construction of roads, for the manufacturing of aggregates for asphalt concrete, ground concrete for pavement and aggregates for surface coatings; while the ZP02 massif presents a poor mechanical characteristic. As specified in the technical specifications, the base layer aggregates of asphalt must have an $\mathrm{MDE}<12$ (Atlan, 1978).

Regarding the results obtained for dynamic fragmentation, the three massifs (ZP01, ZP03 and ZP04) have good characteristics as compared to the ZP02 massif. When the coefficient is less than 25\%, the material is usable in railway construction. On the contrary, if the coefficient is greater than $25 \%$ the material cannot be used in road construction, particularly in the implementation of different layers and especially the base layer. But, the material can be crushed and used as aggregates (gravel in the formulation of concrete). The smaller the coefficient, the more resistant the rock is. Rocks containing quartz as binding materials are more resistant followed by those that contain calcite or ferruginous minerals.
Rocks that content clay are less resistant. Generally, resistance increases with the percentage of quartz (Atlan, 1978). The French geotechnical standard indicates that the Bahkosso, Na'abissa and Kaparang are good for railway construction while the ZP02 massif is not good for rail road construction, but either good for making concrete.

\section{DISCUSSION}

Our petrographic study indicates that the granodiorite formations in the study area and the different massifs of the Beka-Gotto locality share a similar source. The rocks from this magmatic group emerge in the form of balls, blocks, slabs and domes. At the outcrop, the rock is light gray in color. They are generally made of plagioclase, potassium feldspar, biotite and quartz and accessory minerals (zircon and opaque minerals). The mineralogical composition and grain size of the rocks studied play an important role in their resistance. Thus, petrography results will be valuable in the selection of resistant material for construction purposes. The geotechnical tests show that the granodiorite can be used in construction. Based on the results of physiomechanical tests obtained, the granodioritic massif has remarkable resistance. On the base values of resistance to abrasion and fragmentation, the granodiorite can be characterized for road construction and in the formulation of concrete.

The results of the mechanical characteristics of aggregates do not agree with the work of Al-Hadj H. Z. (2014) that focused on the geotechnical characterization granites in the Ouaddai region in eastern Chad. On the petrographic level, it obtains two types of granite: biotite granite, granite consisting fineto medium-grained quartz, orthoclase, plagioclase biotite, and biotite granite and amphibole, mediumto coarse-grained, consisting of quartz, orthoclase, plagioclase, biotite, amphibole and opaque minerals. On the other hand, in the Beka-Gotto locality we found only one magmatic set: granodiorite that does not have the same mineralogical compositions than the biotite and amphibole granite observed in the Ouaddai region. From a geotechnical point of view, the LA coefficient of the four biotite and amphibole granites samples in the Ouaddai region of class 10/14 are respectively $33 \%, 33 \%, 30 \%$, and $29 \%$. These show that the results are clearly satisfactory to that obtained at the level of the Beka-Gotto granodioritic 
massif, with LA coefficient values over the four samples $24 \%, 46 \%, 33 \%$, and $30 \%$,respectively. The Micro-Deval value of $7 \%, 8 \%, 7 \%$, and $7 \%$, are significantly lower than that obtained value at the Beka-Gotto granodioritic massif which are $9 \%, 38 \%$, $8 \%$, and $7 \%$. And finally the biotite and amphibole granite of the Ouaddai region presents the values of dynamic fragmentation coefficient $(21 \%, 20 \%, 20 \%$, and $15 \%$ ) that is clearly lower than that obtained at the level of the granodioritic massif of Beka-Gotto $(20 \%$, $30 \%, 21 \%$, and $18 \%$ ).

The biotite and amphibole granite obtained in the Ouaddai region overall present better characteristics than the granodioritic of Beka-Gotto, which represents satisfactory characteristics on three quarters of all of its massifs. We think this could be a result of moderate alteration in some parts of the Beka-Gotto massifs. Youogo (2018) carried out the petrographic and geotechnical characterization of Foto-Menouet, which shows that there is a plutonic formation made up of microgranites, porphyroid granites, syenogranites and aplitic granites. While, at the level of the BekaGotto massifs there is a magmatic set made up of only granodiorite. From a geotechnical point of view, the materials from the Foto-Menouet deposit show a LA coefficient of 24.7 on the class 10/14, and a MicroDeval of 9.06 , a specific weight of $2600 \mathrm{~kg} / \mathrm{m} 3$ and an apparent density of $1.39 \mathrm{~g} / \mathrm{cm} 3$. Hence, it can be seen that the results of the various geotechnical tests carried out by Youogo (2018) are practically identical to the results obtained at the granite massif of BekaGotto region.

\section{CONCLUSIONS}

Examination of the results shows a great homogeneity of the substratum and it highlights that the granites from the Beka-Gotto massif have excellent characteristics. However, some small irregularities were noticed in the Gbago massif (ZP02). This could be explained by the mineralogical composition, grain size, and rock fracturing, which play a significant role on the quality of the material and the weathering of the rock. In accordance with geotechnical standards, the rocky massif of Beka-Gotto has good quality and usable for civil engineering works (manufacture of any crushing aggregates for asphalt concrete, ground concrete for pavement and aggregates for surface plasters).

\section{ACKNOWLEDGEMENTS}

Part of this work was carried out in A-Z Consulting Laboratory and in University of Dschang in the framework of the Master thesis of Aboubakar Abdoul. The authors express their sincere gratitude to the Head staff of A-Z Consulting for carrying geotechnical analysis, and to the thin section laboratory of the
Earth Sciences Department of University of Yaoundé 1. We are grateful to anonymous reviewers for their suggestions to improve the manuscript.

\section{AUTHOR'S CONTRIBUTIONS}

A. Aboubakar and B. I. Manefouet proposed the current research, which is part of the Master thesis research work of the first author. A. Aboubakar, L. S. Komguep, E. T. Talom and Y. L. Djonthu conducted field work and sampling. A. Aboubakar, E. T. Talom, C. R. Foueze and Y. L. Djonthu wrote the paper and prepared the figures following acquiesced data. A. Aboubakar, B. I. Manefouet, L. S. Komguep contributed the work with observations and comments in analyzing data and interpretation. All the authors discussed, reviewed, and finalized the paper.

\section{REFERENCES}

Affaton, P., Rahaman, M.A., Trompette, R., Sougy, J., 1991, The Dahomeyide Orogen: Tectono thermal evolution and relationship with the Volta Basin. In: Dallmeyer, R.D., Lécorché, J.P. (Eds.), the West African Orogens and Circum-Atlantic Correlatives. Springer-Verlag, 107-122.

AFNOR NF EN 1097-2, 2010, Essais pour déterminer les caractéristiques mécaniques des granulats Partie 2: méthode pour la détermination de la résistance a` la fragmentation. $32 \mathrm{p}$.

AFNOR NF P18-572, 2005, Essais pour déterminer les caractéristiques mécaniques des granulats Partie 2: Méthode pour la détermination de la résistance à l'usure. $30 \mathrm{p}$.

Al-Hadj, H. Z., 2014, Caractérisation géotechnique des granites de la région de l'Ouaddaï (EST -TCHAD) en vue de leur utilisation en génie civil. Mémoire Master ès Science. Université de Dschang, 20 p.

Atlan Y., 1978, Catalogues des essais géotechniques exécutés au laboratoire géotechnique d'Orléans. 240-270.

Bessoles, B., Trompette, R., 1980, Géologie de l'Afrique: La chaîne panafricaine "zone mobile d'Afrique centrale (partie sud) et zone mobile soudanaise ». Mémoire du Bureau de Recherches Géologiques et Minières Orléans, France, 92, 397.

Dumort, J.C., 1968, Carte géologique de reconnaissance au 1/500.000. Imprimerie Nationale, D.M.G. 340 Yaoundé.

Kamgang, K., 1998, Evolution supergène des rocheset incidence phytogéographique: Cas du contact forêtsavane au Sud-Est Cameroun. Thèse d'état, SC. Nat, Univ. Yaoundé I, 208 p.

Lassere, M., 1966, Géochronologie du Cameroun Rapport d'activité scientifique (1962 à 1966). B.R.G.M, Paris-Orléans, 74 p.

Lasserre, M., Soba, D., 1979, Migmatisation d'âge 
panafricain au sein des formations camerounaises appartenant à la zone mobile d'Afrique centrale. Comptes Rendus Sommaires Société Géologique de France 2, 64-68.

Ngako, V., 1999, Les deformations continental panafricaines en Afrique Centrale. Résultat d'un poinçonnement de type himalayen. Thèse Doctorat D'Etat, Université de Yaoundé I, 241 p.

NOMAD, 2012, Congrès international francophone sous le thème 'Nouveau Matériaux et Durabilité'.

Segalen, P., 1967, Les sols et la géomorphologie du Cameroun. Cahier ORSTOM, 2, 137-187.

Toteu, S. F., Penaye, J. and Djomani Poudjom, Y., 2004, Geodynamic evolution of the Pan-African belt in
Central Africa with special reference to Cameroon. Canadian Journal of Earth Sciences, 41, 73 -85.

Van, Schmus, W.R., Oliveira, E.P., Da, Silva,Filho, A.F., Toteu, S.F., Penaye, J. et Guimaraes, I.P., 2008, Proterozoic links between the Borborema Province, NE Brazil, and the Central African Fold Belt. In: Pankhurst R.J., Trouw R.A.J., Brito Neves B.B. and De Wit M.J. (Eds) West Gondwana: Pre-Cenozoic correlations across the South Atlantic Region. Geological Society, London, Special Publications, 294, 69-99.

Youogo, K., 2018, Caractérisation pétrographique et geotechnique des granitoides de Foto-Menouet par Dschang. Mémoire Master en Science de la Terre. Université de Dschang. 82 p. 